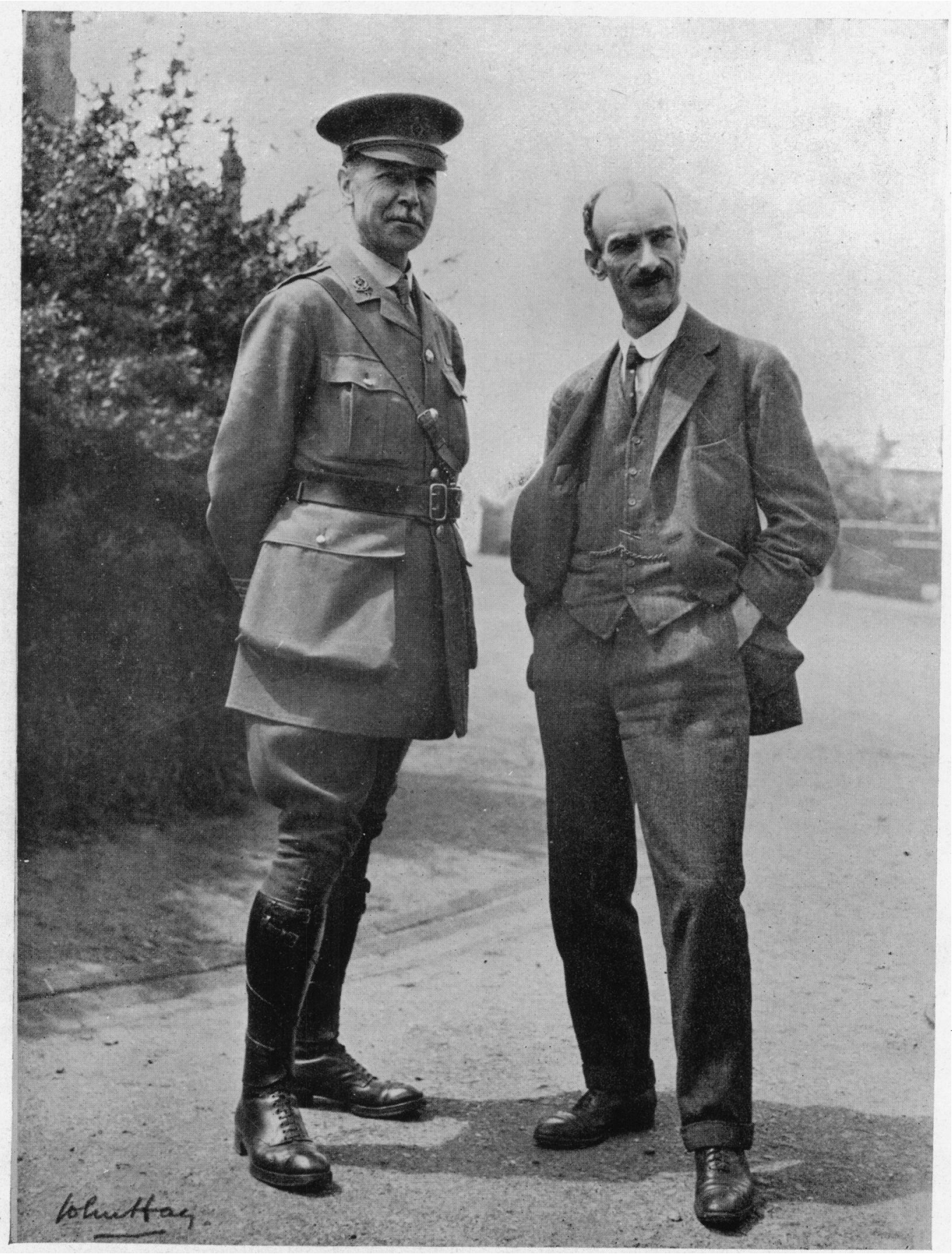

WARDROP GRIFFITH (in uniform) and THOMAS LEWIS during the 1914-18 war.

Photo by John Hay 


\section{THOMAS WARDROP GRIFFITH}

Professor Wardrop Griffith can only have been known personally to few members of the British Cardiac Society, as it is sixty years since he became Professor of Anatomy in the Yorkshire Medical School at Leeds: and he flourished as a physician in the generation between those of Clifford Allbutt and of the present most senior physicians in Leeds.

Wardrop Griffith was born in 1861, the tenth child and eighth son of Charles Fox Griffith, J.P., of Aberdeen. He was educated at the Aberdeen Grammar School, and the University of Aberdeen, where he qualified in April 1882 with the highest honours. After qualification he acted as demonstrator in anatomy to John Struthers for four terms, and under that master got a thorough training in dissecting-room anatomy.

In October 1883 he took the post of house physician at Leeds General Infirmary, and the next year was appointed the resident medical officer. This post he retained until his appointment as Professor of Anatomy in the Yorkshire College in Leeds in 1887. As this was a part-time Chair, Griffith put up his plate in Park Square, and started practice as a physician. In 1892, in addition to his professorship of anatomy, he was appointed an honorary assistant physician at the Leeds General Infirmary. In 1904 he was elected physician in charge of outpatients, and became a full honorary physician in 1905, from which post he retired in 1925. He held the Professorship of Anatomy up to the year 1910, when he became Professor of Medicine; he resigned the chair in 1925, when he retired from the Leeds Infirmary.

Wardrop Griffith made a great reputation as a teacher of anatomy. Despite the fact that he obtained the chair at the early age of 26 years and also that it was a part-time post, he took the School of Anatomy at Leeds to the front rank, both by the thoroughness of his work and his brilliance as a lecturer. As pointed out by an old student in the Yorkshire Post on October 29, 1946, " He was a pupil of the great John Struthers, and inherited from him an exact and lucid conception of anatomy, and a great power of elucidating much of its mysteries. He was a man who impressed students, and no student ever played the fool at his lectures. His presence in the dissecting room was always welcome, and his demonstrating powers were of a high order." He had examined in Anatomy in the Natural Science Tripos and the 2nd M.B. examination at Cambridge.

There was something of the dramatic in Griffith's teaching, of which those of us who heard him talk in the Cardiac Society and at the Association of Physicians were well aware. In his anatomical lectures he was wont to jump on to a table to illustrate the action of muscles and joints, and was wont to perform other acts of pantomime. His students, when they came together in after years, took pleasure in recalling their memories of Wardrop Griffith, chiefly as a teacher of anatomy with his little mannerisms, his punctuality, and his kindliness.

While holding the Chair of Medicine, his lectures were equally lucid and thorough, and his teaching at the Infirmary was very sound, but it is doubtful whether he ever produced quite the same atmosphere as obtained at his lectures in anatomy. Griffith was extremely assiduous and punctual in all his hospital and university duties, and expected punctuality from others as well. He identified himself very closely with the Leeds Medical School, and so great was his share in this, that it was said that, " he personally supervised the laying of every brick." As Dr. Veale stated, while presenting Griffith for the Honorary D.Sc. in 1929, "There is little over-statement in this, for the University owes him a lasting debt of gratitude for the careful planning and sound construction of this building, which now, though being substantially enlarged, still remains a lasting memorial of his efforts." 
In the clinical school he founded the clinic for diseases of the skin, and was one of the first to make use of the graphic methods of cardiovascular investigation suggested by the work of James Mackenzie and Thomas Lewis.

Wardrop Griffith was one of the original members of the Cardiac Club when it was founded in 1922, and in the early years was very regular in his attendance, and could always be relied upon to give an authoritative opinion on any anatomical question. In 1924 he opened a discussion on the heart in pneumonia. He was, however, already getting senior and most of his active writing had already been done so that he was elected an Extra-Ordinary Member as long ago as 1928. In the third volume of Heart he published an exhaustive paper on two cases of heart block, in which he noted the ausculatory phenomenon of auricular beats. He gave the Schorstein lecture on some cardiac problems in 1912. He was a critical worker and Thomas Lewis gave much importance to his opinion, and often submitted work for his criticism. In Griffith's home circle, "Thomas Lewis" became a family saying, meaning he was thinking about something else!

Griffith had taken the M.R.C.P. in 1901 and was elected F.R.C.P. in 1908. He served on the Council of the Royal College of Physicians from 1924 to 1926 . He acted as examiner in Medicine in the Universities of Cambridge and Manchester. In 1922 his own University of Aberdeen conferred upon him its Doctorate of Law, and Leeds University conferred upon him the Honorary Degree of Doctor of Science.

Tall, well proportioned, and good looking, there was a certain charm of manner in Wardrop Griffith, which made him very approachable to younger members of the profession, and he was a real friend to all the early members of the Cardiac Club, and was intensely interested in any work that any of them were doing. His memory was prodigious, and he could reel off pages of poetry chiefly of the lighter kind such as Gilbert and Sullivan, Bab Ballads, etc. $\mathrm{He}$ was an authority on the Waverley novels, and knew the stories and characters well. He had also the same intimate knowledge of Dickens and Thackeray.

During the War of 1914-18, Wardrop Griffith served with Number 2 Northern General Hospital at Beckett's Park, Leeds, and in 1918 was appointed C.M.G. From 1918-27, he represented the University of Leeds on the General Medical Council.

Being one of ten children, he always kept in touch with the remaining brothers and their children: his two sisters died fairly early in life. The evening of Wardrop Griffith's life was saddened by the loss of his wife in 1937, and the gradual loss of his eyesight, so that he was unable to read for the last three years.

We mourn the loss of our most senior member, whose youthful outlook on medicine kept him in touch and sympathy with his junior colleagues long after he had retired from the active staff of the Leeds Infirmary, at a time when his great clinical experience and critical outlook was most helpful.

\section{W. E. HUME}

Thirteen years ago, when I attended the meeting of the Cardiac Club at Leeds, I have a clear memory of Wardrop Griffith: of the distinguished way he presided over the meeting, of his lucid demonstration of specimens of congenital heart disease, and of his kindness to me a very junior member of the Club. It has, therefore, been a great pleasure with the help of John Towers, compiling this bibliography of his publications on cardiology. His first paper, in 1889 , written for his M.D. thesis, was on 50 cases of empyema, but very soon he had started his interest in congenital heart disease. His remaining papers dealt mainly with other anatomical abnormalities and with nervous diseases.

MAURICE CAMPBELL 
Remarks on fifty consecutive cases of empyema occurring in the medical wards of the general infirmary at Leeds. Med. Chron. (1888-9), 9, 441.

A case of transposition of the thoracic and abdominal viscera, with congenital malformation.of the heart and of the arterial and venous systems. J. Anat. \& Physiol. (1891-2), 26, 117.

Heart with imperfection of the septum of the ventricles and other anomalies. Proc. Anat. Soc. Gt. Brit. \& Ire. (1896-7), p. 18.

Example of a large opening between the two auricles of the heart unconnected with the fossa ovalis. J. Anat. \& Physiol. (1899), 33, 261.

Obstruction of the inferior vena cava. J. Anat. \& Physiol. (1899), 33, 503.

Specimen of great redundancy of the fossa ovalis. J. Anat. \& Physiol. (1899), 33, 502.

Two examples of moderator band in the left ventricle of the heart. J. Anat. \& Physiol. (1899), 33, 31.

Remarks on aneurysm of the coronary arteries of the heart. Brit. Med.J. (1931), 1, 266.

Abnormalities of the heart. J. Anat. \& Physiol. (1902), 36, 26.

A case of almost complete absence of the auricular septum and other cardiac malformations complicated by acquired mitral disease. Med. Chron. (1903), 37, 385.

An example of a peculiar malformation of the tricuspid valve of the heart. J. Anat. \& Physiol. (1903), 38, 251.

Note on a second example of division of the cavity of the left auricle into two compartments by a fibrous band. J. Anat. \& Physiol. (1903), 37, 255.

On affections of the tricuspid valve of the heart, with a note on a pedunculated thrombus occurring in the right auricle. Edin. Med. J., N.S. (1903), 13, 105.

Infective endocarditis involving the pulmonary valves and associated with imperfection of the inter-auricular septum. Lancet (1906), 11, 973.

On a case of combined disease of the mitral, aortic, and tricuspid valves of the heart, in which the patient was under observations for 25 years. Lancet (1907), 2, 1147.

Unusual diseases of the heart. Brit. Med.J. (1909), 2, 142.

Venous pulse in neck. Brit. Med. J. (1909), 1, 720.

(with A.E. Cohn): Remarks on the study of a case showing a greatly lengthened a-c interval with attacks of partial and of complete heart block. Quart. J. Med. (1910), 3, 126.

Remarks on two cases of heart block. Heart (1911-12), 3, 143.

The Schorstein lecture on some cardiac problems. Brit. Med. J. (1912), 11, 913.

(with A. M. Kennedy): A case of complete auriculo-ventricular heart block with a report of the pathological condition of the heart. Brit. Med.J. (1913), 1, 1203.

A presidential address on the development of our knowledge of the diseases of the heart. Lancet (1913), 11, 1517.

(with A. M. Kennedy): Supplementary note on a case of heart block; with an examination of the auriculo-ventricular junctional tissue. Heart (1914-15), 6, 37.

Remarks on a communication between the two ventricles of the heart occupying an unusual situation. Lancet (1915), 1, 59.

Two cases of patency of the ductus arteriosus. Quart. J. Med. (1915), 8, 191.

Embolic aneurysm of peripheral arteries. Lancet (1920), 11, 374.

A clinical study of three cases of heart block. Brit. Med.J. (1921), 1, 763, and 956.

(with J. Hay et al.): Discussion on cardiac irregularities: especially in reference to prognosis and treatment. Brit. Med.J. (1924), 11, 697. 